Biografistyka Pedagogiczna

Rok 1 (2016) nr 1

ISSN 2543-6112; e-ISSN 2543-7399

DOI: $10.36578 /$ BP.2016.01.09

Piotr Gołdyn

\title{
Kilka słów o spotkaniu świętości i nierządu w przestrzeni biograficznej
}

\section{A Few Words about the Meeting of Sanctity and Debauchery in Biographical Dimension}

\begin{abstract}
Although sanctity and debauchery do not usually go hand in hand, they often come across each other in various dimensions. The biographical aspect certainly is among them, and these meetings have a reciprocal influence on the representatives of sanctity and debauchery. The former bolster their holiness by serving the morally fallen women, the latter receive support and gain the courage to change their lives. There are numerous such meetings, from Christ and for example his meeting with Mary Magdalene, through the activities of Maria Karłowski, which resulted in the foundation of a religious congregation aimed the social rehabilitation of prostitutes, Sister Luitbergia Janiszewska, or the present activities of Sister Anna Bałchan.
\end{abstract}

Keywords: sanctity, holiness, debauchery, biography

Tak ten świat jest poukładany, że obok siebie koegzystuje i dobro, i zło, które toczą ze sobą odwieczną walkę, kiedy spotykają się w różnych przestrzeniach. Jedną z takich przestrzeni są ludzkie biografie, a takimi przedstawicielami dobra i zła może być i świętość, i nierząd. Przykłady takich spotkań znajdujemy już w Biblii, szczególnie zaś na kartach Nowego Testamentu. W tym przypadku odnoszą się do spotkań Chrystusa z nierządnicami. Jedno z nich opisuje ewangelista Łukasz:

* Piotr Gołdyn - dr hab., prof. Uniwersytetu im. Adama Mickiewicza w Poznaniu, pracuje na Wydziale Pedagogiczno-Artystycznym w Kaliszu, piotr-goldyn@wp.pl. 
Jeden z faryzeuszów zaprosił Go do siebie na posiłek. Wszedł więc do domu faryzeusza i zajął miejsce za stołem. A oto kobieta, która prowadziła w mieście życie grzeszne, dowiedziawszy się, że jest gościem w domu faryzeusza, przyniosła flakonik alabastrowy olejku, i stanąwszy z tyłu u nóg Jego, płacząc, zaczęła łzami oblewać Jego nogi i włosami swej głowy je wycierać. Potem całowała Jego stopy i namaszczała je olejkiem. Widząc to faryzeusz, który Go zaprosił, mówił sam do siebie: „Gdyby On był prorokiem, wiedziałby, co za jedna i jaka jest ta kobieta, która się Go dotyka, że jest grzesznicą”. Na to Jezus rzekł do niego: „Szymonie, mam ci coś powiedzieć”. On rzekł: „Powiedz, Nauczycielu!” „Pewien wierzyciel miał dwóch dłużników. Jeden winien mu był pięćset denarów, a drugi pięćdziesiąt. Gdy nie mieli z czego oddać, darował obydwom. Który więc z nich będzie go bardziej miłował?". Szymon odpowiedział: „Sądzę, że ten, któremu więcej darował”. On mu rzekł: „Słusznie osądziłeś”. Potem zwrócił się do kobiety i rzekł Szymonowi: „Widzisz tę kobietę? Wszedłem do twego domu, a nie podałeś Mi wody do nóg; ona zaś łzami oblała Mi stopy i swymi włosami je otarła. Nie dałeś Mi pocałunku; a ona, odkąd wszedłem, nie przestaje całować nóg moich. Głowy nie namaściłeś Mi oliwą; ona zaś olejkiem namaściła moje nogi. Dlatego powiadam ci: Odpuszczone są jej liczne grzechy, ponieważ bardzo umiłowała. A ten, komu mało się odpuszcza, mało miłuje". Do niej zaś rzekł: „Twoje grzechy są odpuszczone”. Na to współbiesiadnicy zaczęli mówić sami do siebie: „Któż On jest, że nawet grzechy odpuszcza?”. On zaś rzekł do kobiety: „Twoja wiara cię ocaliła, idź w pokoju!” (Łk, 7, 36-50).

Jeszcze inny przykład, może bardziej znany, bardziej powszechny, pochodzi z Ewangelii św. Jana. Kiedy to przyprowadzono do Jezusa kobietę pochwyconą na cudzołóstwie, aby ją osądził, ten jednak odpuścił jej grzechy (J 8,1-11). Różnica między obu spotkaniami jest taka, że w tym pierwszym przypadku było to dobrowolne, $\mathrm{w}$ drugim natomiast przymuszone. W obu jednak efekt był taki sam - odpuszczenie grzechów, powrót do życia bez grzechu, przywrócenie osoby społeczeństwu.

Takie spotkania nie były domeną tylko i wyłącznie Jezusa. Jeśli spojrzymy w nieodległą przeszłość, choćby do końca XIX czy początku XX w. z pewnością dostrzeżemy inne przykłady. Wskazać można chociażby błogosławioną Marię Karłowską.

Jej pierwsze spotkanie z kobietami lekkich obyczajów wyglądało w ten sposób:

Pewnego popołudnia w listopadzie 1892 r. Maria znalazła się w ubogiej suterenowej izbie, gdzie odwiedziła starszych małżonków Grześkowiaków. Wtem weszła nietrzeźwa, wyzywająco ubrana dziewczyna. Grześkowiakowie próbowali usunąc ją z mieszkania, ale Maria przeszkodziła temu i w paru uprzejmych słowach zwróciła się do dziewczyny. Ta powiedziała, że jest prostytutką, znajdującą się pod kontrolą policji obyczajowej, potem nakreśliła smutne koleje swego życia i popro- 
siła Marię o pomoc w zerwaniu z dotychczasowym środowiskiem. Karłowska słuchała najpierw z przerażeniem, a potem z głębokim współczuciem. W prośbie tej dziewczyny odczytała powołanie Boże skierowane do niej. Odtąd poświęciła się całkowicie umoralnieniu kobiet upadłych.

Maria miała wówczas 16 lat. Urodziła się bowiem 4 września 1865 r. jako jedenaste dziecko Mateusza Karłowskiego i Eugenii z Dembińskich. Po śmierci rodziców opiekę na Marią przejęła jej siostra Wanda. Była ona właścicielką pracowni krawieckiej, a młodsza siostra u niej pracowała. Planowała zostać zakonnicą, nawet na ręce swojego spowiednika złożyła śluby czystości. Nie podjęła jednakże życia zakonnego, czekała bowiem na znak Opatrzności².

Tym znakiem okazało się wyżej opisane spotkanie. Odtąd rozpoczęła się wytężona praca Marii Karłowskiej, która przysporzyła jej chwały nieba, a papież Jan Paweł II wyniósł ją na ołtarze i wprowadził w poczet błogosławionych. To spotkanie stało się nie tylko zaczynem pracy resocjalizacyjnej wśród poznańskich prostytutek, ale dało początek nowemu zgromadzeniu zakonnemu, którego głównym charyzmatem jest przywracanie „upadłych kobiet” społeczeństwu.

Te spotkania następowały w różnych miejscach. Często były to bramy kamienic czy cmentarze. Kobiety same zaczęły przychodzić do Marii z prośbą o pomoc. Z kolei Karłowska apostołowała również w szpitalu, na oddziale dla chorych wenerycznie. Zauważano, że miało to pozytywny wpływ na pacjentki. Dzięki spotkaniu z Klementyną Jaworską udało się uruchomić przytułek dla tych kobiet. Mieścił się on w mieszkaniu Jaworskiej, a dziewczęta przebywały tam do momentu wyszukania dla nich jakiegoś „porządnego" zajęcia ${ }^{3}$.

Trzeba zauważyć, że Karłowska była obdarzona wyjątkową intuicją pedagogiczną. Nie miała żadnego przygotowania ani merytorycznego, ani praktycznego w tym zakresie. A opieka nad tymi kobietami nie należała do najłatwiejszych. Najtrudniejsza była praca z tymi, które w pewnym momencie zaczęły podsyłać władze samorządowe. Często stanowiły one zagrożenie dla innych podopiecznych, więc Karłowska

1 Archiwum Zgromadzenia Sióstr Pasterek od Opatrzności Bożej w Jabłonowie Pomorskim [dalej: AZSPOB], MK 110-4/2a, A. Narzymska, Dzieje Zgromadzenia Sióstr Pasterek od Opatrzności Bożej w latach 1893-1935, s. 39-40, mps.

2 W. Rozynkowski, G. Dobrska, Może i tobie Bóg udzieli łaski! O bł. Marii Karłowskiej, Toruń 2005, s. 10-16.

3 A. Narzymska, Dzieje Zgromadzenia, s. 39-40. 
wolała przyjmować te, które zgłaszały się dobrowolnie. Choć i z tymi były problemy. Dziewczęta często dopuszczały się kłamstw czy oszustw. Wspomniana wcześniej Klementyna Jaworska opisywała takie przypadki w swojej kronice. Jeden z nich dotyczył niejakiej Bernardy, która zgłosiła się do przytułku prowadzonego przez Karłowską. Poinformowała Marię, że jest sierotą, że nie posiada żadnej rodziny i prosi o przyjęcie. Maria przyjęła ją, choć miała przeczucie, że wersja przedstawiona nie do końca jest prawdziwą. Przypuszczenia te potwierdziły się kilka dni później, gdy zjawiła się matka Bernardy, która chciała zabrać córkę do domu. Kiedy oszustwo wyszło na jaw, to matka postanowiła rozpocząć pracę nad własną córką ${ }^{4}$.

W zakładach prowadzonych przez Marię Karłowską, a później także przez zakonnice ze zgromadzenia sióstr pasterek obowiązywał skromny strój dla dziewcząt. Nie mogły one zachowywać tego „ze świata”, gdyż często ubrania te były objawem próżności, a same dziewczęta lubiły bardzo różnego rodzaju świecidełka. Oto jeden z przykładów:

W tym czasie Matka Przełożona odprawiała rekolekcje z Pokutnicą Wandą. Była to osoba z lepszym wychowaniem, ale tym większa grzesznica. Złota w jej stroju nie brakowało. Po pewnym czasie, kiedy ją przebierano z pięknych sukienek, szalała wprost, że miała się z nimi pożegnać, chociaż już od paru miesięcy chodziła do Matki Marii, aby przyjęła ją do Dobrego Pasterza. Mówiła: - Jaka ja jestem nieszczęśliwa, że tą Matuchnę poznałam! - Narzekała, że przychodziła co niedzielę, a teraz Matuchna zabiera jej złoty zegarek i te piękne pierścienie, i te trafione włosy, z którymi musi się pożegnać! 5 .

Dziewczęta te miały również „niesamowite” pomysły. Czasem Maria Karłowska wykazywała się niezwykłą cierpliwością i pomysłowością, aby opanować niecodzienne zachowania i nawyki podopiecznych. Kolejny przykład:

[...] Marta z Bronisławą nie pomyślały nawet w posłuszeństwie. Na środku dziedzińca był ogromny stóg równający się wysokością ze stodołą, ułożony z witek, które nie nadawały się do wyrabiania koszy, lecz zostały przeznaczone na opał. Szatan podszepnął im, aby udały się na tę ogromną stertę chrustu. Z wielką radością wykonały swój zamiar. W jednej chwili były już na jej wierzchołku i postanowiły tam pozostać przez całą noc. Stamtąd mogli je widzieć wszyscy przechodnie, mieszkańcy Winiar. Był to okropny widok patrzeć na te Dusze pokutujące, pełne

4 AzsPoB w Jabłonowie Pomorskim, Kronika Domu Dobrego Pasterza 1892-1900, sygn. MK 49/4, S. 136-138 (dalej: Kronika).

5 Tamże, s. 93. 
ironii i szyderstwa z Sióstr, że teraz będą musiały pilnować je przez całą noc. Nie zachowały się tam spokojnie, ale zaczepiały przechodniów swymi nawoływaniami i krzykami. [...] Rano było trudniej, aniżeli poprzedniego dnia, bo niewyspane i głodne stały się bardziej rozbestwione, a w czasie rannej rekreacji zaczęły zaczepiać spokojne Dusze i buntować je. [...] Około południa zaczął padać deszcz. Lecz i to nie pomogło, aby zeszły na dół i tak, całe zmoczone, pozostały w swym uporze.

Aby nie przedłużać tego stanu rzeczy, Karłowska użyła sposobu, żeby ściągnąć niepokorne pokutnice ze sterty. Wdrapały się na nią siostry, które poczęły rozrzucać z góry gałęzie, zmniejszając w ten sposób tę stertę. Obniżyła się ona mniej więcej o połowę, co pozwoliło „ukryć" dziewczęta przed wzrokiem przechodniów, a tym samy zachować ich od obelg rzucanych przez wychowanki

Główną troską Marii Karłowskiej były dusze powierzonych jej dziewcząt, dlatego często starała się organizować dla nich odpowiednio prowadzone rekolekcje. Jako przykład nawrócenia stawiała wówczas osobę Marii Magdaleny. W jednym roku zorganizowano takie rekolekcje w formie nowenny przed uroczystością poświęconą tej świętej. Już pierwszego dnia ich trwania Karłowska rozważała z pokutnicami fakt nawrócenia Marii Magdaleny, porzucenia przez nią dotychczasowego życia i starania o wytrwanie w łasce nawrócenia. Kolejnego dnia starała się uzmysłowić swoim podopiecznym, że one same są dopiero na początku tej drogi nawrócenia, drogi poprawy.

Matka stwierdziła, że u nich do pokuty jest tak daleko, jak od nieba do ziemi i dodała, że nie myśli wcale zachęcać ich do pokuty, tylko do miłości Pana Boga, a wtedy jeżeli prawdziwie kochać będą, zrozumieją i pokochają pokutę

Niestety, nie do wszystkich dziewczyn te słowa trafiały, mimo że tematyka kolejnych konferencji oscylowała wokół chęci nawrócenia i wytrwania w pokucie. Kilka z dziewcząt podburzało kolejne przeciwko Marii i innym zakonnicom. Tu jednak Karłowska okazała swoją konsekwencję i zamiast uroczystego nabożeństwa na koniec nowenny, w uroczystość św. Marii Magdaleny, odbyła się tylko krótka modlitwa9.

Oczywiście Karłowska wiedziała, że nie tylko słowa, ale przede wszystkim przykłady mogą stać się impulsem do podjęcia działań zmierzających do poprawy przez

6 Tamże, s. 130-131.

7 Tamże, s. 131.

8 Tamże, s. 121.

9 Tamże, s. 123-125. 
wychowanki. Do dawania takiego przykładu mobilizowała siebie, ale także zachęcała swoje zakonnice.

W Wielki Czwartek nastąpiło umywanie nóg. Jedynie Matka Maria umywała i całowała nogę każdej Pokutnicy, posuwając się na klęczkach od jednej do drugiej. Pokutnice drżały z przerażenia, wołając: - Najukochańsza Matuchno, nie czyń tegoo, bo już nie wytrzymamy, tak nas parzy Twój pocałunek na naszym grzesznym ciele! - Jedna z nich miała nawet ugniłe palce u jednej nogi i tę to nogę zażądała Matka do umycia i ucałowania. Zanosiły się więc od płaczu i mówiły: - Ta nasza Matka tak się dla nas poświęca, a gdy Pan Jezus nas zapyta, jak korzystałyśmy z tego? - I każda wypowiadała swe zdanie. Piękne były skutki w takim kierownictwie. Przez długi czas widać było skruchę, a wiele Pokutniczek nawróciło się ${ }^{10}$.

Dla Marii Karłowskiej było jasne, że jednym z ważnych elementów wychowania resocjalizacyjnego była praca.

Uważała pracę jako podwalinę dla uświęcenia wszystkich, także Pokutnic. Okazało się, że te, które mają ducha pracy, można prędzej czy później doprowadzić do normalnego życia" ${ }^{11}$.

Tu jednak napotykano na pewne trudności, a wynikały one przede wszystkim z niechęci do pracy wychowanek. Większość z nich nie potrafiła nic, nie pracowały bowiem wcześniej, a często również nie wyniosły żadnych umiejętności z domu. Oczywiście pracę dopasowywano do umiejętności i predyspozycji pokutnic. Karłowska wychodziła jednakże z założenia, że zmuszanie do pracy wbrew predyspozycjom może przynieść negatywne skutki. Zamiłowanie do pracy wiązała z wrodzonymi umiejętnościami. Wobec leniwych podopiecznych zalecała stanowczość, którą należało jednakże połączyć z cierpliwością i wyrozumiałością. Ta, która porzuciła przypisane jej działanie, nie dostawała innego zatrudniania ${ }^{12}$.

Póki wychowanka leniwa nie nabędzie pracowitości, znak to iż nie została jeszcze umoralniona i nie wolno zwalniać jej z zakładu ${ }^{13}$.

Te zaś, które nie potrafiły utrzymać dyscypliny w pracowni, kierowane były do innych prac, zwykle cięższych, na przykład w polu, na roli. Cięższe warunki pracy

10 Tamże, s. 71.

11 Tamże, s. 98-99.

12 M. Karłowska, Duch Pasterek w powołaniu apostolskim, Poznań 1910, s. 29.

13 A. Narzymska, Dzieje Zgromadzenia, s. 82. 
powodowały, że dziewczęta chętnie wracały do swoich poprzednich zajęć, przy których się wcześniej nieco buntowały ${ }^{14}$.

Bunty wśród dziewcząt wybuchały dość często, ale w tym przypadku Karłowska uważała, że do ich stłumienia, wyciszenia najodpowiedniejszym środkiem będzie praca. Praca miała również zająć pokutnice, żeby w wolnym czasie nie powodować ich rozprężenia. Wtedy bowiem przychodziły im najróżniejsze pomysły: czy to rozpamiętywały swoje życie przed pobytem w zakładzie, czy też planowały ucieczki. Szczególnie niebezpieczne były w tym zakresie dni świąteczne.

[...] Matka Maria wymyśliła pracę niedzielną, aby zły duch nie korzystał z długich dni świątecznych, by Dusze nie zaprzątały głów złymi myślami. Matka Przełożona udała się do Najprzewielebniejszego Księdza Arcypasterza z prośbą, czy pozwala na niedzielną pracę wyrabiania obrazków religijnych, na co otrzymała dyspensę ${ }^{\prime 15}$.

W czasie prac czytano dziewczętom książki i czasopisma ${ }^{16}$.

Specyfiką spotkania człowieka z człowiekiem jest interakcja. Wynika z niej obopólna korzyść, choć nie zawsze jest to widoczne od razu. Podczas spotkania świętości i nierządu w przestrzeni biograficznej dzieje się podobnie. Gdy patrzymy na Marię Karłowską, wydaje się, że każde jej spotkanie z nierządnicą było formą nauki, w tym przypadku drugiego człowieka, nauki resocjalizacji, swoistą autopedagogizacją. Dla dziewcząt - nierządnic, przynajmniej tych, które tego chciały, kontakt z Marią był z pewnością czymś w rodzaju katharsis, one czerpały z Karłowskiej, ile tylko mogły, zmieniając w ten sposób swoje życie, stając się zupełnie innymi osobami, kobietami, o których nie można już było powiedzieć, że są upadłe. Nie zawsze potrafiły to osiągnąć w bezpośrednim kontakcie z Marią, dlatego

[...] praca Matki nad Pokutnicami powiększyła się, bo nowa - jakby można powiedzieć - łaska spłynęła na ich serca. Kilka Pokutnic zaczęło prowadzić z Matką duchową korespondencję. Te liściki Pokutnice przesyłały przez Siostry, a Matka dawała im odpowiedzi. Pokutniczka po otrzymaniu odpowiednich rad i upomnien, nieraz w obszernym liście, skorzystała więcej, aniżeli z konferencji, bo tak ośmielona wynurzała się z tajnych często rzeczy, co by sprawiało jej wielką trudność, gdyby miała powiedzieć ustnie ${ }^{17}$.

14 Tamże, s. 83.

15 Kronika, s. 95.

16 A. Narzymska, Dzieje Zgromadzenia, s. 87-88

17 Kronika, s. 160. 
Sama Maria Karłowska uważała, że jej pedagogia sprawiała, iż około 80\% kobiet poddawanych resocjalizacji w placówkach prowadzonych przez siostry pasterki osiągała pozytywne rezultaty. Czy jest to liczba odpowiadająca faktom, trudno to zweryfikować. Wiadomo jednakże, że spotkanie z Karłowską dla tych dziewcząt było zbawienne. Wracały do rodzin, zajmowały się uczciwą pracą. Niektóre z nich jednakże, mimo przemiany obawiały się powrotu do życia poza zakładem. Nie czuły się godne na przykład wychodzić za mąż, ponadto przyzwyczaiły się do trybu życia w zakładzie i nie potrafiły funkcjonować w inny sposób, wiele z nich z pewnością bało się również możliwości powrotu, do „profesji”, do bycia prostytutką ${ }^{18}$.

Nie chciały więc opuszczać zakładu, jednakże nie mogły wstąpić do zgromadzenia. W trosce o te dziewczęta Maria Karłowska założyła specjalnie dla nich Stowarzyszenie Sióstr Magdalen. Pozostawały one przy zgromadzeniu. Karłowska opracowała dla nich strój, „Magdaleny” nosiły popielate suknie i biały welon. Składały również specjalne przyrzecznie, zobowiązując się do życia pokutnego i świecenia przykładem dla wychowanek przebywających w domach zakładu. Głównym miejscem pobytu „Magdalen" było Pniewite, a matka Karłowska, dopóki żyła, poświęcała im wiele uwagi. Swoją obecnością i przykładem utwierdzała je w wybranej przez nie drodze $e^{19}$.

Warto w tym miejscu poświęcić nieco uwagi jeszcze jednej zakonnicy, siostrze Luitbirdze Janiszewskiej ze zgromadzenia sióstr elżbietanek. Co prawda nie została ona wpisana w poczet błogosławionych, ale swoim życiem świadczyła o świętości. Wraz z ks. Stanisławem Budaszewskim prowadziła „Dom św. Elżbiety” przeznaczony dla kobiet „moralnie upadłych”.

Luitbirga Janiszewska przyszła na świat w Toruniu, 19 listopada 1886 r. Wiadomo, że jej ojciec był urzędnikiem, zaś nie wiadomo zbyt wiele o matce. Na chrzcie dano jej na imię Elżbieta. Do zgromadzenia sióstr elżbietanek wstąpiła już jako w miarę dojrzała kobieta, miała wówczas 24 lat. Swoją formacjęzakonną rozpoczęła w klasztorze we Wrocławiu, jednakże już w drugim roku nowicjatu przeniesiono ją do Poznania, z którym związała się do końca życia. Jako pielęgniarka posługiwała ubogim na poznańskich Jeżycach, a następnie włączyła się do pracy we wspomnianym „Domu św. Elżbiety”.

Do stałej pomocy w tej akcji miała panią świecką, która przebywała w „Przystani” stale, a s. Luitbirga dochodziła tam kilkakrotnie w ciągu dnia i zaopatrywała wszystkie potrzeby domu. „Przystań” miała charakter zakładu półotwartego, z którego

18 P. Gołdyn, Pogarda dla zawodu, litość dla człowieka. Społeczno-edukacyjne formy działalności wobec kobiet zagrożonych prostytucją w Polsce (1918-1939), Kalisz 2013, s. 244-245.

19 Tamże, s. 245. 
dziewczęta łatwiej i szybciej przechodziły do normalnego życia wśród społeczeństwa. S. Luitbirga była dla dziewcząt troskliwą matką, pełną wyrozumienia i poświęcenia. Pracy nad dziewczętami oddawała się bez reszty, pełna ufności i przekonania, że trud się opłaca. Praca tego rodzaju prowadzona taką metodą, była w owych czasach nowością i przez nasze Zgromadzenie dotychczas nie była podejmowaną. Stąd s. Luitbirga spotykała się często z brakiem zrozumienia tak ze strony niektórych osób świeckich, duchownych, a także i sióstr własnego zgromadzenia ${ }^{20}$.

Na barkach siostry Janiszewskiej spoczywało i administrowanie domem, i wychowywanie dziewcząt, to do niej musiały zwracać się z prośbą o pozwolenie na wyjście poza placówkę. Siostra wyznaczała im także zajęcia i prace do zrealizowania w placówce. Otrzymywały je oczywiście te dziewczęta, które nie miały stałej pracy i pozostawały w domu.

Wiele kobiet, które były pod wypływem działań wychowawczych siostry Luitbergi, już po opuszczeniu „Domu św. Elżbiety” utrzymywało z nią kontakt listowny. Bardzo często prosiły o ponowne przyjęcie do placówki, bowiem nie zawsze potrafiły się odnaleźć w innym świecie. Niektóre prośby przepełnione były determinacją. Dziewczęta były zdecydowane na wszystko, byle tylko ponownie mogły znaleźć się pod opiekuńczymi skrzydłami siostry Janiszewskiej. Dowodem na to może być fragment listu:

[...] jak najusilniej proszę Przewielebną Siostrę o przyjęcie. Chciałam wszystko wytrzymać i pracować jeszcze do drugiego roku ale jest niemożliwem, mimo najszczerszych chęci. Niech mi przebaczy przewielebna Siostra wszystko złe, ja się zastosować postaram, żeby wszystko naprawić. Gdybym wiedział, że mogę wrócić, gotowa jestem iść pieszo do Poznania²1.

Zdarzały się przypadki, że siostra odmawiała ponownego przyjęcia dziewcząt do placówki, powody były różne. Nie zawsze możliwe dziś do odtworzenia, ale można przypuszczać, że powody musiały być poważne. Jedna z dziewcząt żaliła się, że jej siostra nie chciała na powrót mieć w swojej placówce.

Smutno bardzo a zarazem i przykro że siostra tak twarde serce ma dla mnie, nie przypuszczałam nigdy że po tych latach pobytu w zakładzie siostra mnie nie przyjmie do siebie ${ }^{22}$.

20 Archiwum Sióstr Elżbietanek w Poznaniu [dalej: ASEP], Wspomnienie pośmiertne, brak sygn. 21 Tamże, sygnn. 4, List, 26 kwietnia 1938 (Kaliska).

22 P. Gołdyn, Korespondencja wychowanek „Domu św. Elżbiety” w Poznaniu (1929-1939) jako źródło do dziejów resocjalizacji kobiet upadłych moralnie, „Poznańskie Zeszyty Humanistyczne", 6 (2006) s. 129-139. 
Nie wiadomo, jak siostra reagowała na tego typu prośby i czy się im przychylała. Jedno jest istotne, dziewczęta odczuwały potrzebę przebywania z siostrą Janiszewską lub chciały mieć z nią kontakt, choćby listowny. Cieszyły je listy od zakonnicy. Jedna z nich tak opisała sytuację, kiedy otrzymała list od siostry Luitbergi.

Kiedy rano już miałam wszystko w pożątku ${ }^{23}$ dzieci na ogrodzie się bawiły, a ja siedziałam jeszcze w swoim pokoju przychodzi pan dziedzic i swoim donośnym głosem woła Honorciu list jest dla Honorci tak się ucieszyłam, że zapomniałam powiedzieć „dzień dobry” dziedzic się śmiał i mówił, że takiego dzieciaka nie widział jak ja jestem on mnie tem bardzo ubliża, bo ja przecież niemogę być jeszcze dzieckiem jak mam cztery dzieci pod opieką nie? ${ }^{24}$.

Dziewczęta często pisały również o swoich zwykłych, codziennych problemach, jak na przykład o przygotowaniu do bierzmowania. Jedna z nich napisała siostrze, że właśnie się przygotowuje do bierzmowania i do spowiedzi, ale nie pójdzie do niej jeśli przyjedzie obcy ksiądz. Inna z kolei bała się wojny ${ }^{25}$.

Siostra przychodziła z pomocą dziewczętom, które przebywały poza domem. Takim przykładem może być jej reakcja - choć nie wiadomo dokładnie, na czym ona polegała - na list, w którym jedna z dawnych podopiecznych żaliła się, że nie może znaleźć pracy, że życie jej zbrzydło, i że zamierza odebrać sobie życie. Do tragedii jednak nie doszło, właśnie dzięki interwencji siostry ${ }^{26}$.

Dziewczęta przebywające w „Domu św. Elżbiety”, a także po jego opuszczeniu, odczuwały duży respekt do s. Luitbergi.

Zdziwi się siostrę zapewne że ta odepchnięta i dawno zapomniana po tak długim czasie ośmiela się list napisać. Już przez cały ten czas ani na chwilę nie zapomniałam o siostrze zawsze dręczyły mnie myśli by przeprosić za krzywdy wyrządzone siostrze lecz brak było mi odwagi [...]. Bo czy mogłabym na zawsze tak

23 W całym cytacie została zachowana pisownia oryginalna.

24 ASEP, sygn. 4, List, 12 sierpnia 1938 (zachowana pisownia oryginalna).

25 P. Gołdyn, Korespondencja wychowanek, s. 129-139.

26 Tenże, Ulżyć doli kobiety. Działalność resocjalizacyjna siostry Luitbirgi Janiszewskiej wobec prostytutek w Poznaniu (1929-1940), w: Wnuczki Pandory. Kobieta w społeczeństwie od starożytności do współczesności, red. A. Głowacka-Penczyńska, K. Grysińska-Jarmuła, M. Opioła-Cegiełka, Bydgoszcz 2016, s. 167-183. 
zapomnieć? Nie nigdy przecież była mi siostra drogą jak własna matka. Przecież siostra wyrwała mnie z rąk obcych brudnych za co powinnam po kolanach czołgać się do siostry i dziękować a ja tak niewdzięcznie postąpiłam [...]. Ale choć jestem w tej chwili w tej wielkiej Warszawie lecz prowadzę się jakbym była pod ręką siostry ${ }^{27}$.

Jedna ze świeckich współpracownic siostry Luitbergi tak wspominała jej pracę z dziewczętami w „Domu św. Elżbiety”:

Była ona na pewno, najlepszą, najtroskliwszą, pełną wyrozumienia i poświęcenia matką i opiekunką dla swych pupilek. Pracy na dziewczętami oddawała się bez reszty, pełna ufności i przekonania, że trud się opłaca. Toteż w chwilach niepowodzeń (np. liczniejszych ucieczek z Domu) nigdy nie załamywała rąk, wierzyła zawsze, że w ostatecznym wyniku dobro zwycięży, a trudzić warto się chociażby dla jednej tylko duszy ${ }^{28}$.

Analizując powyższe przykłady, zarówno Marii Karłowskiej, jak i s. Luitbergi Janiszewskiej, wyraźnie widać, że spotkania świętości i nierządu w przestrzeni biograficznej są jak najbardziej możliwe. Co więcej, widoczne jest tu wzajemne oddziaływanie, które przynosi korzyści obu stronom. Osoby duchowne utwierdzają się w swoim powołaniu, służbie potrzebującym wsparcia na drodze resocjalizacji, ale także jak wówczas to rozumiano, na drodze do nawrócenia. Dla nierządnic spotkanie z obu kobietami było impulsem do zmiany swojego życia. Nabierały odwagi do walki, do zerwania z dotychczasowym życiem. Dla obu stron było to działanie niezwykle korzystne. Dla sióstr również spotkania z krnąbrnymi nierządnicami były pouczające, uczyły przede wszystkim konsekwencji.

Powyższe przykłady są nieco odległe w dziejach. Ale również dziś do takich spotkań dochodzi. Wystarczy choćby spojrzeć na pracę siostry Anny Bałchan, ze zgromadzenia sióstr marianek, która na Górnym Śląsku poświęca się dla kobiet dotychczas pracujących na ulicach w charakterze prostytutek ${ }^{29}$.

27 ASEP, sygn. 4, List, 23 grudnia 1935 (Warszawa).

28 ASEP, sygn. 4, Wspomnienie Haliny Walczak.

29 A. Bałchan SMI, Kobieta nie jest grzechem. Z siostra [...] o problemie prostytucji (i nie tylko) rozmawia Katarzyna Wiśniewska, Kraków 2007. 
Streszczenie: Choć świętość i nierząd nie idą na co dzień w parze, to jednakże często dochodzi do ich spotkania na różnych płaszczyznach. Jedną z nich jest z pewnością przestrzeń biograficzna, a spotkania te mają obopólny wpływ na reprezentantów świętości i nierządu. Ci pierwsi utrwalają swoją świętość służąc kobietom moralnie upadłym, ci drudzy otrzymują wsparcie i nabierają odwagi do zmiany swojego życia. Przykładów takich spotkań można wymienić wiele. Począwszy od Chrystusa i na przykład jego spotkania z Marią Magdaleną, poprzez działalność Marii Karłowskiej, która zaowocowała założeniem zgromadzenia zakonnego ukierunkowanego na resocjalizację prostytutek, czy siostry Luitbergi Janiszewskiej, do obecnej działalności siostry Anny Bałchan.

Słowa kluczowe: świętość, nierząd, biografia

\section{Bibliografia}

Archiwum Sióstr Elżbietanek w Poznaniu.

Archiwum Zgromadzenia Sióstr Pasterek od Opatrzności Bożej w Jabłonowie Pomorskim.

Bałchan A. SMI, Kobieta nie jest grzechem. Z siostra [...] o problemie prostytucji (i nie tylko) rozmawia Katarzyna Wiśniewska, Kraków 2007.

Gołdyn P., Korespondencja wychowanek „Domu św. Elżbiety” w Poznaniu (1929-1939) jako źródło do dziejów resocjalizacji kobiet upadłych moralnie, „Poznańskie Zeszyty Humanistyczne”, 6 (2006) s. 129-139.

Gołdyn P., Pogarda dla zawodu, litość dla człowieka. Społeczno-edukacyjne formy działalności wobec kobiet zagrożonych prostytucją w Polsce (1918-1939), Kalisz 2013.

Gołdyn P., Ulżyć doli kobiety. Działalność resocjalizacyjna siostry Luitbirgi Janiszewskiej wobec prostytutek w Poznaniu (1929-1940), w: Wnuczki Pandory. Kobieta w społeczeństwie od starożytności do współczesności, red. A. Głowacka-Penczyńska, K. Grysińska-Jarmuła, M. Opioła-Cegiełka, Bydgoszcz 2016, s. 167-183.

Karłowska M., Duch Pasterek w powołaniu apostolskim, Poznań 1910.

Rozynkowski W., G. Dobrska, Może i tobie Bóg udzieli łaski! O bł. Marii Karłowskiej, Toruń 2005. 